\title{
Customer Satisfaction Survey of Pacific Northwest National Laboratory's Technical Assistance Partners - FY 2011
}

\author{
Prepared by: Robin L. Conger \\ Gary E. Spanner
}

November 2, 2011

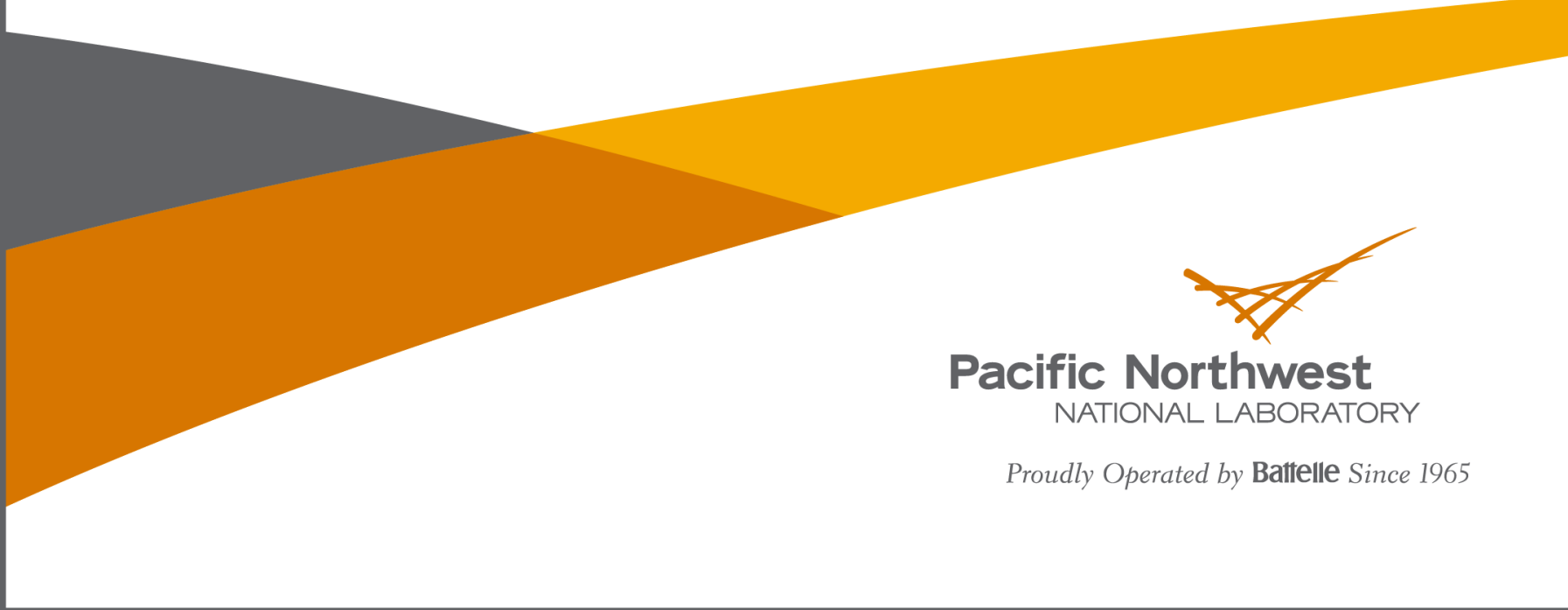




\title{
DISCLAIMER
}

This report was prepared as an account of work sponsored by an agency of the United States Government. Neither the United States Government nor any agency thereof, nor Battelle Memorial Institute, nor any of their employees, makes any warranty, express or implied, or assumes any legal liability or responsibility for the accuracy, completeness, or usefulness of any information, apparatus, product, or process disclosed, or represents that its use would not infringe privately owned rights. Reference herein to any specific commercial product, process, or service by trade name, trademark, manufacturer, or otherwise does not necessarily constitute or imply its endorsement, recommendation, or favoring by the United States Government or any agency thereof, or Battelle Memorial Institute. The views and opinions of authors expressed herein do not necessarily state or reflect those of the United States Government or any agency thereof.

\author{
PACIFIC NORTHWEST NATIONAL LABORATORY \\ operated by \\ BATTELLE \\ for the \\ UNITED STATES DEPARTMENT OF ENERGY \\ under Contract DE-AC05-76RL01830
}

Printed in the United States of America
Available to DOE and DOE contractors from the Office of Scientific and Technical Information,
P.O. Box 62, Oak Ridge, TN 37831-0062;
ph: (865) 576-8401
fax: $(865)$ 576-5728
email: reports@adonis.osti.gov

\begin{abstract}
Available to the public from the National Technical Information Service, U.S. Department of Commerce, 5285 Port Royal Rd., Springfield, VA 22161 ph: (800) 553-6847 fax: $(703) 605-6900$ email: orders@ntis.fedworld.gov online ordering: http://www.ntis.gov/ordering.htm
\end{abstract}

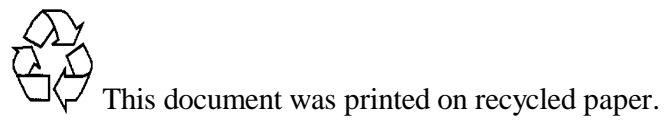




\section{Customer Satisfaction Survey of Pacific Northwest National Laboratory's Technical Assistance Partners - FY 2011}

RL Conger

GE Spanner

November 2, 2011

Prepared for the U.S. Department of Energy

under Contract DE-AC05-76RL01830

Pacific Northwest National Laboratory

Richland, Washington 99352 


\section{Customer Satisfaction Survey of Pacific Northwest National Laboratory's Technology Assistance Partners -- FY 2011}

\subsection{Background}

As part of its small business outreach, Pacific Northwest National Laboratory (PNNL) offers technology assistance to businesses with fewer than 500 employees throughout the nation and to businesses of any size in the 2 counties that contain the Hanford site. Upon request, up to 40 staff-hours of a researcher's time can be provided to address technology issues at no charge to the requesting firm. During FY 2011, PNNL completed assistance for 54 firms. Topics of the technology assistance covered a broad range, including environment, energy, industrial processes, medical, materials, computers and software, and sensors. In FY 2011, PNNL's Technology Assistance Program (TAP) was funded by PNNL Overheads. Over the past 16 years, the Technology Assistance Program has received total funding of nearly $\$ 2.8$ million from several federal and private sources.

\subsection{Survey Approach}

E-mail surveys were sent to 36 firms that received technology assistance that was completed by the end of FY 2011. The surveys (sample attached), designed to be answered in 5 minutes or less, consisted of 8 questions on a single page. Out of 36 surveys sent, 18 of them, or $50 \%$, were filled out and returned.

The first two questions on the survey were to be answered using a five-point scale:

1 - Very Dissatisfied

2 - Dissatisfied

4 - Satisfied

3 - Neutral

5 - Very Satisfied

NA - Not Applicable

The next six questions were to be answered by yes, no, or not applicable, with room for comments.

\subsection{Survey Results}

The results of the survey are summarized and then responses to each question are described.

\subsection{Summary of Results}

The mean score for all responses to the first two questions combined was 4.8 out of $5.100 \%$ of the respondents were satisfied or better with the administration of PNNL's Technology Assistance Program. $100 \%$ of the respondents were satisfied or better with the usefulness of the technology assistance provided by PNNL. 100\% would rely on PNNL for technology support in the future. Among those who received recommendations from their technology assistance, $86 \%$ either have implemented, or definitely plan to implement, the recommendations.

\subsection{Results by Question}

The results of each question are described in this section. Each question is presented in bold, followed by the aggregate response to the question.

\section{Overall, how would you rate the administration of the Technology Assistance Program?}


Of 18 responses to this question, the mean score was 4.8 out of $5.100 \%$ of the respondents were satisfied or better with the administration of PNNL's Technology Assistance Program.

2. Please rate the usefulness of the technology assistance provided by PNNL.

Of 18 responses to this question, the mean score was 4.8 out of $5.100 \%$ of the respondents were satisfied or better with the usefulness of the technology assistance provided by PNNL.

3. Have the recommendations you received been implemented in your operations? If not, will they be implemented and approximately when?

Twelve firms have implemented, or plan to implement, the recommendations. Among respondents for whom this question was applicable, $86 \%$ have, or definitely plan to, implement recommendations received.

4. Did the assistance you received increase the quality of your products, increase the efficiency of your operations, or result in new or improved products? If so, briefly describe.

Thirteen respondents reported increases in quality, increases in efficiency, or new products. Among those respondents for whom this question was applicable, $87 \%$ reported quality or efficiency improvements, new products, or other benefits, now or in the future.

5. As a result of the assistance you received, were any jobs retained or created, and if so, how many full-time equivalent jobs and what types? Number of jobs? Number of displaced Hanford workers hired? Type of jobs (please describe).

Three respondents indicated they had created or retained 7.5 (total) jobs as a result of the assistance (one had created .5 of an FTE, while the other two respondents were able to retain 5 and 2 jobs, respectively.)

6. What is the number of full-time equivalent employees currently at your firm? Has this number changed over the last two years? If so, by how much (increase or decrease)?

Total employment for the 17 firms that responded is 409.5 FTEs. For these firms there was a net increase of 34 FTEs over the past two years (six firms reported a combined increase of 69 FTEs, while four firms reported a decrease of 35 FTEs.)

7. Based on PNNL's performance this fiscal year, would you rely on PNNL for support in the future?

Of the 18 respondents to this question, 100\% stated that they would rely on PNNL for technology support in the future.

\section{Please provide any other suggestions you have concerning how PNNL could improve the efficiency and effectiveness of its Technology Assistance Program for industry.}

There were fourteen responses to this question, many of which were comments of thanks or support for the program and the technical staff and encouragement for continuing the program as is. The following specific recommendations were made:

- Provide a running balance of the number of hours being expended so the small business can better utilize the allotted time.

- Provide a directory of available assistance and contact information to reach the assistance providers directly.

- Use collaborative tools like Google Documents or Lotus Notes so that the small business and research staff can interact with each other in real time on the research.

- More communication to ensure alignment of expectations with regards to timing of the project 
completion and certain terms and conditions.

\subsection{Conclusions}

It can be concluded that PNNL's Technology Assistance Program was well received by the businesses it served in FY 2011. 100\% of the respondents would rely, or already have relied, on PNNL for technology support in the future. 